\title{
A sensitive microextraction by packed sorbent-based methodology combined with ultra-high pressure liquid chromatography as a powerful technique for analysis of biologically active flavonols in wines
}

\author{
Catarina L. Silva, João L. Gonçalves, José S. Câmara* \\ CQM/UMa, Centro de Química da Madeira, Centro de Ciências Exactas e da Engenharia da Universidade da Madeira, Campus Universitário da Penteada, 9000-390 Funchal, Portugal
}

\section{H I G H L I G H T S}

- An innovative methodology to pre-concentrate bioactive flavonols, MEPS.

- Rapid screening for analysis of biological active flavonols in wines.

- MEPS reduced the sample volume and the time necessary for the analysis.

- Limits the consumption of organic solvents thus also reducing the testing cost.

- Good results were obtained in terms of selectivity, precision, sensitivity and accuracy.

\section{A R T I C L E I N F O}

\section{Article history:}

Received 31 March 2012

Received in revised form 8 June 2012

Accepted 11 June 2012

Available online 19 June 2012

\section{Keywords:}

Wines

Flavonols

Microextraction by packed sorbent

Solid phase extraction

Ultra high pressure liquid chromatography
G R A P H I C A L A B S T R A C T

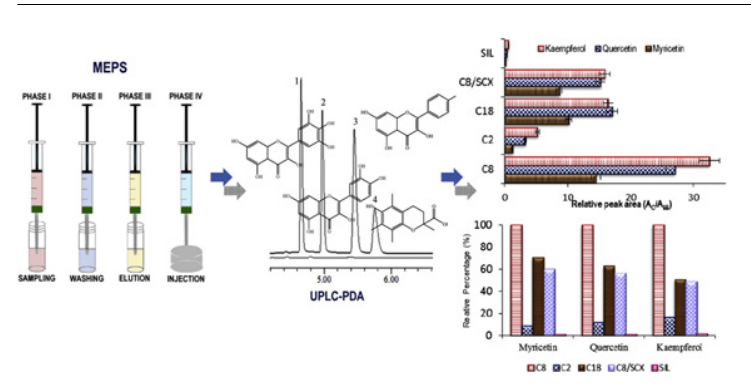

\begin{abstract}
A B S T R A C T
A new approach based on microextraction by packed sorbent (MEPS) and reversed-phase highthroughput ultra high pressure liquid chromatography (UHPLC) method that uses a gradient elution and diode array detection to quantitate three biologically active flavonols in wines, myricetin, quercetin, and kaempferol, is described. In addition to performing routine experiments to establish the validity of the assay to internationally accepted criteria (selectivity, linearity, sensitivity, precision, accuracy), experiments are included to assess the effect of the important experimental parameters such as the type of sorbent material (C2, C8, C18, SIL, and C8/SCX), number of extraction cycles (extract-discard), elution volume, sample volume, and ethanol content, on the MEPS performance. The optimal conditions of MEPS extraction were obtained using C8 sorbent and small sample volumes $(250 \mu \mathrm{L})$ in five extraction cycle and in a short time period (about $5 \mathrm{~min}$ for the entire sample preparation step). Under optimized conditions, excellent linearity ( $R_{\text {values }}^{2}>0.9963$ ), limits of detection of $0.006 \mu \mathrm{g} \mathrm{mL}^{-1}$ (quercetin) to $0.013 \mu \mathrm{g} \mathrm{mL}^{-1}$ (myricetin) and precision within $0.5-3.1 \%$ were observed for the target flavonols. The average recoveries of myricetin, quercetin and kaempferol for real samples were 83.0-97.7\% with relative standard deviation (RSD, \%) lower than $1.6 \%$. The results obtained showed that the most abundant flavonol in the analyzed samples was myricetin $\left(5.8 \pm 3.7 \mu \mathrm{g} \mathrm{mL}^{-1}\right)$. Quercetin $\left(0.97 \pm 0.41 \mu \mathrm{g} \mathrm{mL}^{-1}\right)$ and kaempferol $\left(0.66 \pm 0.24 \mu \mathrm{g} \mathrm{mL}^{-1}\right)$ were found in a lower concentration.
\end{abstract}

\footnotetext{
* Corresponding author. Tel.: +351 291705112; fax: +351291705149.

E-mail address: jsc@uma.pt (J.S. Câmara).
} 
The optimized MEPS ${ }_{C 8}$ method was compared with a reverse-phase solid-phase extraction (SPE) procedure using as sorbent a macroporous copolymer made from a balanced ratio of two monomers, the lipophilic divinylbenzene and the hydrophilic N-vinylpyrrolidone (Oasis HLB) were used as reference. MEPS $_{C 8}$ approach offers an attractive alternative for analysis of flavonols in wines, providing a number of advantages including highest extraction efficiency (from $85.9 \pm 0.9 \%$ to $92.1 \pm 0.5 \%$ ) in the shortest extraction time with low solvent consumption, fast sample throughput, more environmentally friendly and easy to perform.

() 2012 Elsevier B.V. All rights reserved.

\section{Introduction}

Flavonols are recognized as a subclass of flavonoids, distributed ubiquitously in the plant kingdom, from which the most common are kaempferol, quercetin and myricetin. The formation of flavonols myricetin, quercetin and kaempferol (Fig. 1) in grapes has been reported to occur through the phenylpropanoid metabolism [1]. Specifically, naringenin is transformed into quercetin and kaempferol by means of the enzyme flavanone $3 \beta$-hydroxylase (FHT), which leads to the production of dihydroflavonols [1-3]. Regarding myricetin, although it is also produced through the phenylpropanoid metabolism, its synthesis occurs in general terms further in the pathway [4-6].

These molecules are present in the grape mainly in the monoglycoside form, with the sugar residue linked to the hydroxyl group in position $\mathrm{C}-3$ of the $\mathrm{O}$-containing ring, but substitution can also occur at the $5^{\prime}, 7^{\prime}, 4^{\prime}, 3^{\prime}$, and $5^{\prime}$-positions [7]. The glycoside flavonols kaempferol, quercetin, and myricetin (Fig. 1) form co-pigments with anthocyanins (in red wines); together with oxidation products of tannins, are in the main responsible for the color of white grapes and wines.

Flavonoids have long been recognized to exhibit antiinflammatory, antioxidant, anti-allergic, hepatoprotective, antithrombotic, anti-viral, anti-carcinogenic activities and immune modulating functions, among others [8-11]. The flavonoids also act as potent metal chelators and free radical scavengers and are powerful chain-breaking antioxidants [12], and control protein oxidation and advanced glycation end products (AGEs) formation [13]. By acting as free radical scavengers, flavonoids inhibit lipid peroxidation that can initiate LDL oxidation, a contributing factor to the development of atherosclerosis [14-19]. Epidemiological studies have shown that there is an inverse association between the intake of flavonols and flavones and the risk of coronary heart disease [20-22], stroke [23] and lung cancer [24]. The position and the degree of hydroxylation have been demonstrated to be the most important for their biochemical and pharmacological actions [25,26]. Wang et al. [11] examined the antioxidant and antiinflammatory activities of selected flavonols, including kaempferol, quercetin and myricetin. Their results showed that flavonols exhibit distinctive antioxidant and anti-inflammatory potentials and that the structures, required to strengthen these activities, vary with sorts of free radicals and mechanisms. Quercetin blocked the aggregation of human platelets by ADP and thrombin, and this compound has gained considerable prominence as an inhibitor of carcinogens and of cancer cell growth in many experimental and human tumors $[27,28]$.

The essential part of flavonol structure for exerting such activity is the 0 -dihydroxyl structure at the $3^{\prime}$ - and $4^{\prime}$-position of the B-ring $[29,30]$. Hydroxyl groups at the $3^{\prime}$ and $4^{\prime}$-position scavenge free radicals by donation of hydrogen or an electron. Quercetin and myricetin can exert strong antioxidant activity because they possess an o-dihydroxyl structure, so-called catechol and pyrogallol, respectively [31]. Kaempferol is a weak antioxidant because of its monophenol structure in the B-ring [29].

Due to their proposed health-promoting effects, it is important to develop efficient and high throughput analytical methods able to assess the amount of flavonols in food commodities. In recent years, increasing knowledge of the positive health effects of food polyphenols has prompted the need to develop new separation techniques for their extraction, fractionation and analysis [29,32-34]. Many analytical methods have been described for determination of flavonols in wines. The most selective methods involve often liquid or gas chromatography coupled to detection by mass or tandem mass spectrometry [35-48].

Conventional techniques, based mainly on liquid-liquid extraction (LLE) and solid-phase extraction (SPE), are reported for analysis of wine flavonols. However, these procedures are quite timeconsuming and need relatively high volume of solvent/sample, which is not appropriate for the routine analyses of many food commodities. Over the last years the-increasing demand for control analysis has contributed markedly to the renewal of interest in miniaturized analytical techniques. The usage of less amounts or no solvent, increasing sensitivity of analysis and user-friendly systems, should be pointed out. In this context, the microextraction by packed sorbent (MEPS) has emerged as an attractive alternative for sample preparation due to its simplicity, little solvent consumption (as small as $10 \mu \mathrm{L}$ ), the need of very small sample volumes, and can be easily interfaced to LC-MS [49] and GC-MS to provide a completely automated MEPS/LC-MS or MEPS/GC-MS system [50-52]. The commercially available MEPS uses the same sorbents as conventional SPE columns and so is suitable for use with most existing methods by scaling the reagent and sample volumes. Unlike conventional SPE columns, the MEPS sorbent bed is integrated into a liquid handling syringe that allows for low void volume sample manipulations either manually or in combination with laboratory robotics. When the sample has passed through the solid support, the analytes are adsorbed to the solid phase packed in a barrel insert and needle (BIN) $[46,49]$. The cartridge bed can be packed or coated to provide selective and suitable sampling conditions. Silicabased reversed phase (C2, C8 and C18), strong cation exchanger (SCX) using sulfonic acid bonded silica, restricted access material (RAM), HILIC, carbon, polystyrene-divinylbenzene copolymer (PS-DVB) or molecular imprinted polymers (MIPs), can be used as adsorbent materials. This extraction technique (MEPS) could be of interest in clinical, forensic toxicology and environmental analysis areas $[49,53,54]$.The ultra high pressure liquid chromatography (UHPLC) has recently become a fast separation technique. The development of analytical columns of very small particle size and specially designed instruments allow for the use of much lower flows of mobile phase at very high pressures, which results in increased speed of analysis, higher separation efficiency and resolution, higher sensitivity and much lower sample and solvent consumption as compared to other analytical approaches.

The current research study reports the development and validation of an ultra-fast, efficient, sensitive, reliable and high throughput MEPS-based methodology combined with UHPLC equipped with a PDA detection system, for the simultaneous determination of biologically active flavonols in wines. As stationary phase a new T3 bonding process (HSS T3), which utilizes a trifunctional $\mathrm{C}_{18}$ alkyl phases bonded at ligand density that promotes polar compound retention and aqueous mobile phase compatibility, in order to analyze a large batch of samples in a short period 
(A)

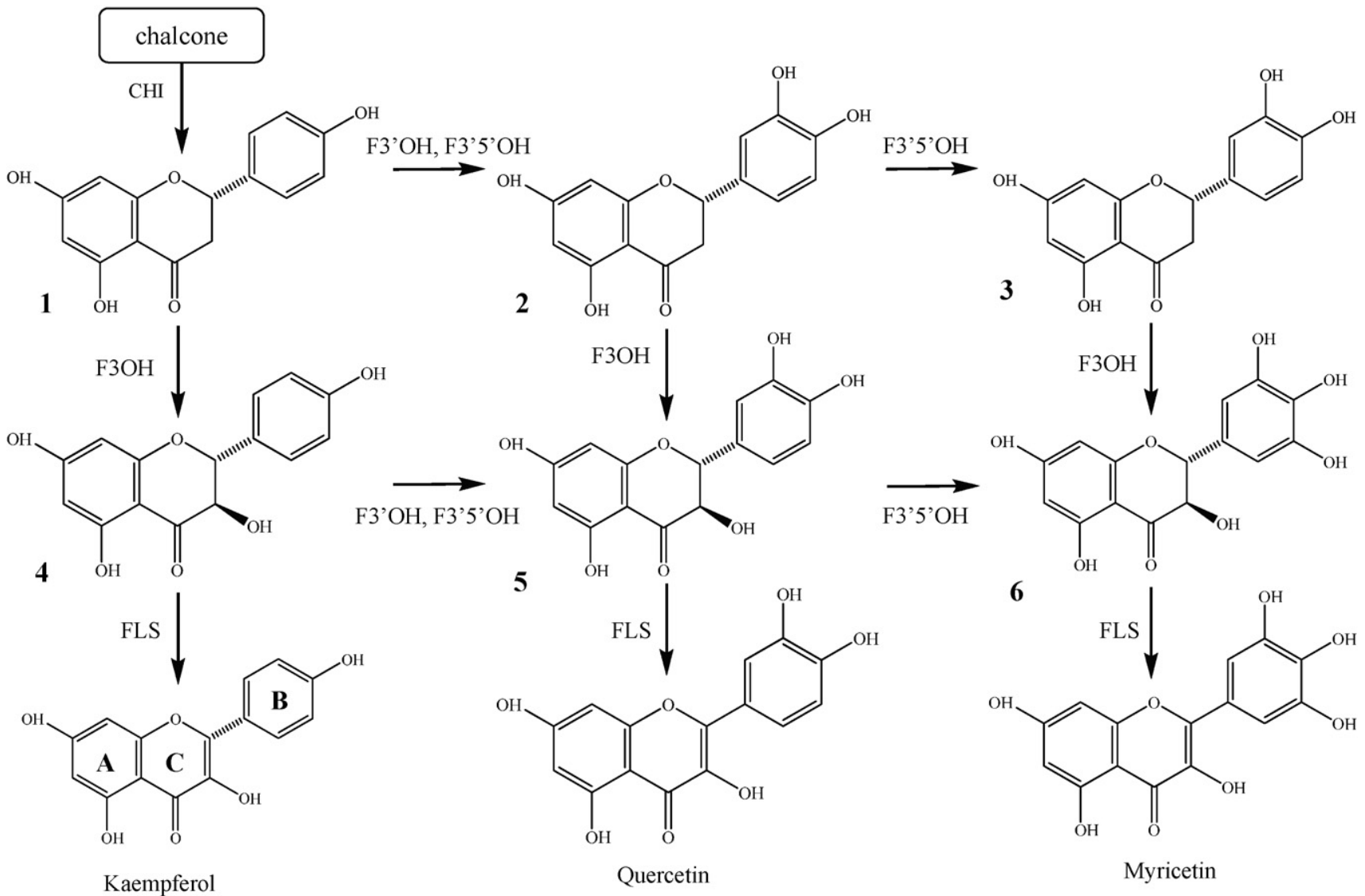

(B)<smiles>Cc1c(C)c2c(c(C)c1O)CCC(C)(C(=O)O)O2</smiles>

Trolox

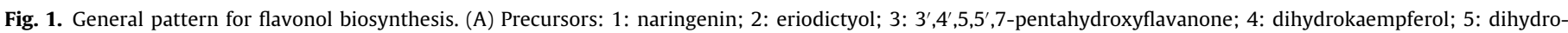

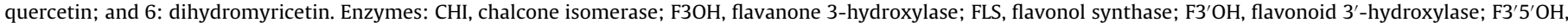
flavonoid 3',5'-hydroxylase, and (B) Trolox chemical structure.

of time. Spiked synthetic wine solution, red wine (RW\#3) and white wine (WW\#26) were used to evaluate the performance of the developed method. Parameters affecting the MEPS extraction efficiency, such as type of sorbent material, number of extraction cycles (extract-discard), volume of eluent and sample volume, were carefully optimized. The method was compared to SPE technique commonly used for wine polyphenols analysis and applied to thirty wine samples from different varieties and vintage.

\section{Experimental}

\subsection{Materials}

LC-gradient grade methanol (99.9\% purity) was obtained from Sigma-Aldrich (St. Louis, MO, USA), formic acid from Merck, (Darmstadt, Germany) and acetic acid from Riedel-de-Haën (Germany). Ethanol absolute (99.5\% purity) and sodium hydroxide were obtained from Panreac (Barcelona, Spain). Kaempferol and Trolox (internal standard) were acquired from Fluka Biochemica AG (Buchs, Switzerland), and tartaric acid from Sigma-Aldrich. Myricetin was acquired from Acros Organics (Geel, Belgium). Ultrapure water $\left(18 \mathrm{M} \Omega \mathrm{cm}\right.$ at $\left.23^{\circ} \mathrm{C}\right)$ was obtained by means of a Milli-Q water purification system (Millipore, Milford, MA, USA). All the extracts were filtered through $0.22 \mu \mathrm{m}$ PTFE membrane filters. The MEPS gas-tight syringe $(250 \mu \mathrm{L})$ and the BIN containing the sorbent material from SGE Analytical Science (Melbourne, VIC, Australia). The Waters Acquity UPLC HSS T3 analytical column $(100 \mathrm{~mm} \times 2.1 \mathrm{~mm}, 1.8 \mu \mathrm{m}$ particle size $)$ was purchased from Waters (Waters, Milford, MA, USA). A HANNA instruments pH209 $\mathrm{pH}$ meter (Woonsocket, USA) was used to $\mathrm{pH}$ adjustments.

\subsection{Instrumentation}

The analysis of flavonols was carried out on a Waters UPLC, Acquity $\mathrm{H}$-Class system combined with a Waters Acquity quaternary solvent manager (QSM), an Acquity sample manager (SM), a 
column heater, a 2996 PDA detector, and an in-line degasser system. The whole configuration was driven by Empower software v2.0 from Waters Corporation. Optimum separation was achieved with a binary mobile phase which consisted of (A) water containing $0.1 \%$ formic acid, and (B) methanol, with a constant flow rate of $250 \mu \mathrm{L} \mathrm{min}^{-1}$, giving a maximum back pressure of $6000 \mathrm{psi}$, which is within the capabilities of the UHPLC. $2 \mu \mathrm{L}$ of extracts were injected into the Waters Acquity UPLC system, equipped with an Acquity UPLCTM strength silica HSS T3 analytical column ( $1.8 \mu \mathrm{m}$ particle size, $2.1 \mathrm{~mm} \times 100 \mathrm{~mm})$ and protected with an Acquity UPLCTM HSS T3 Van GuardTM Pre-column (Waters); column temperature was thermostated at $40^{\circ} \mathrm{C}$ and the samples were kept at $4{ }^{\circ} \mathrm{C}$ in the sample manager. All solvents and samples were filtered through $0.22 \mu \mathrm{m}$ pore size membrane filters, degassed ultrasonically and pumped in gradient mode through the chromatographic system as follows: $80 \% \mathrm{~A}(0 \mathrm{~min}) ; 80-70 \% \mathrm{~A}$ (0.50 $\mathrm{min})$; 68\% A (1 min); 20\% A (7 min); and 80\% A (7 min), followed by a re-equilibration time of 2 min, for bringing the column to the initial conditions after gradient analysis, resulted in a total analysis time of $9 \mathrm{~min}$.

\subsection{Procedures}

\subsubsection{Standard solutions}

Analytical standard stock solutions of each flavonol $\left(1000 \mu \mathrm{g} \mathrm{mL}^{-1}\right)$ were prepared in pure ethanol, aliquoted in $4 \mathrm{~mL}$ vials, coded and stored at $-20^{\circ} \mathrm{C}$, in the dark; under these conditions they were stable for at least 4 month (as assessed by UHPLC). A working standard multicomponent solution was prepared daily from the individual stock solutions by diluting them in synthetic wine $\left(5 \mathrm{~g} \mathrm{~L}^{-1}\right.$ tartaric acid, $12 \%(\mathrm{v} / \mathrm{v})$ ethanol and $8 \mathrm{~g} \mathrm{~L}^{-1}$ of sugar (glucose: fructose, 1:1). This standard was used both, to spike the wines to perform the assays for optimization of extraction conditions and for calibration studies [55,56]. The concentration ranges (Table 1 ) were selected in function of sensitivity of the UHPLC-PDA towards each flavonol compound. Trolox was used as internal standard (IS).

\subsubsection{Wine samples}

Thirty representative wine samples from different vintages, grape varieties, and from different Portuguese regions (mainland, Madeira and Azores Islands), produced according to standard procedures were kindly donated by the winemakers.

Synthetic wine was prepared by adding $5 \mathrm{~g} \mathrm{~L}^{-1}$ of tartaric acid and $8 \mathrm{~g} \mathrm{~L}^{-1}$ of sugar (glucose: fructose, $1: 1$ ) to ethanol solution at $12 \%(\mathrm{v} / \mathrm{v})$. Synthetic wine $\mathrm{pH} 3.4$ was adjusted with sodium hydroxide $1 \mathrm{M}$.

To minimize the influence of ethanol on extraction efficiency, wine samples and synthetic wines were dealcoholized under vacuum at $40^{\circ} \mathrm{C}$, up to $1 / 4$ of initial volume. The volume of dealcoholized extracts was adjusted to initial sample volume with ultrapure water. The aqueous extracts were used for both techniques (MEPS and SPE). All samples were analyzed in triplicate.

\subsubsection{Flavonols extraction}

2.3.3.1. Optimization of the factors affecting the MEPS performance. The MEPS procedure was carried out by means of a SGE Analytical Science apparatus (I.L.C., Lisbon, Portugal), consisting of a $250 \mu \mathrm{L}$ gas-tight syringe with a removable needle. The syringe was fitted with a BIN containing $4 \mathrm{mg}$ of the sorbent material and was used to draw and discharge samples and solutions through the BIN. A synthetic wine sample spiked with known amounts of flavonols was used to optimize the MEPS procedure. Several important MEPSinfluencing extraction factors, such as the nature of adsorbent material, number of extraction cycles, elution volume, sample volume, and ethanol content, were evaluated.
At a first step, the performance of the five MEPS sorbent materials, C2 (ethyl-silica), C8 (octyl-silica), C18 (octadecyl-silica), SIL (unmodified silica) and C8/SCX (a mixed mode sorbent containing $80 \%$ C8 and 20\% strong cationic exchange (SCX)) was tested and compared. To select the number of extraction cycles (extractdiscard) and sample volume, an aliquot of $50 \mu \mathrm{L}, 100 \mu \mathrm{L}$ and $250 \mu \mathrm{L}$ of synthetic wine was pumped up and down 1, 5 and 10 times, in order to obtain the best extraction efficiency. Different elution volumes $(50,100,250,350$ and $500 \mu \mathrm{L})$ were also tested. The flow rate during aspiration is limited to about $20 \pm 2.3 \mu \mathrm{Ls}^{-1}$ (average values of $n=12$ assays) to prevent cavitation. This will increase analyte/sorbent contact time and extraction efficiency.

To overcome the co-solvent effect of ethanol towards flavonols and to improve the extraction efficiency, synthetic wine, red wine and white wine samples were dealcoholized under rotoevaporation to $1 / 4$ of initial volume. The volume of the dealcoholized extract was adjusted to initial volume with different solutions to select that gives best results: (a) 100\% water; (b) $90 \%$ aqueous solution of formic acid at $0.1 \%$ and $10 \%$ methanol; and (c) $80 \%$ aqueous solution of formic acid at $0.1 \%$ and $20 \%$ methanol (mobile phase used at initial step of gradient elution). Since the influence of methanol on MEPS polyphenols extraction efficiency was similar to ethanol, and taking into account their use as mobile phase in the UHPLC system, methanol was chosen to evaluate the effect of alcoholic content on extraction efficiency. All optimization procedures were carried out in triplicate.

2.3.3.2. MEPS procedure for flavonols analysis. MEPS experiments were conducted using $4 \mathrm{mg}$ of $\mathrm{C} 8$ sorbent, selected, in the optimization step, as the best sorbent to isolate the target flavonols. Before being used for the first time, the sorbent was manually conditioned first with $100 \mu \mathrm{L}$ methanol and then with $100 \mu \mathrm{L}$ water (containing $0.1 \%$ formic acid). This step activates the sorbent and ensures reproducible retention of the analytes [57,58]. $250 \mu \mathrm{L}$ of sample were passed through the $\mathrm{C} 8$ sorbent five times at a flow rate of about $20 \pm 2.3 \mu \mathrm{Ls}^{-1}$ on average. The solid phase was then washed with $100 \mu \mathrm{L}$ of water containing $0.1 \%$ formic acid to remove interferences, at a speed of about $50 \mu \mathrm{L} \mathrm{s}^{-1}$. The analytes were eluted with $250 \mu \mathrm{L}$ of $95 \%$ methanol and 5\% water directly into a vial. Between every extraction, the sorbent was rinsed with $250 \mu \mathrm{L}$ methanol followed by $250 \mu \mathrm{L}$ of the washing solution ( $0.1 \%$ formic acid aqueous solution). This step decreased memory effects (carry-over), but also functioned as conditioning step before the next extraction. The extracts were filtered through Millipore membrane PTFE filters $(0.22 \mu \mathrm{m}$ particle size $)$. An aliquot of $2 \mu \mathrm{L}$ of this solution was injected in triplicate into the UHPLC-PDA system. The same packing bed was used for about 100 extractions; then it was discarded due to both the low analyte extraction yields and clogging of the sorbent. All MEPS steps including activation, loading, washing, and elution were carried out manually. In all measurements (standards and samples), Trolox was added as internal standard (IS).

2.3.3.3. SPE. The MEPS procedure was compared to SPE reversephase using Oasis HLB extraction cartridges, developed by Silva et al. [43]. Briefly, 1 cc (30 mg) Oasis HLB extraction cartridges were conditioned with $1 \mathrm{~mL}$ of ethyl acetate and methanol and equilibrated with $1 \mathrm{~mL}$ of water. An aliquot of sample $(900 \mu \mathrm{L})$, previously prepared (see Section 2.3.2.) was passed through the SPE cartridges, at around $1.5 \mathrm{~mL} \mathrm{~min}^{-1}$, using an Alltech extraction unit (SGE). The cartridges were washed with a solution of methanol $5 \%$ and subsequently the flavonols were eluted, into the same vial, with $500 \mu \mathrm{L}$ methanol, $1000 \mu \mathrm{L}$ ethyl acetate and finally $500 \mu \mathrm{L}$ methanol. The extracts were evaporated to dryness under a nitrogen stream. The dried residue was dissolved in $1000 \mu \mathrm{L}$ of initial mobile phase ( $0.1 \%$ formic acid aqueous solution and $20 \%$ of methanol solution), homogenized in a vortex agitator and filtered 
Table 1

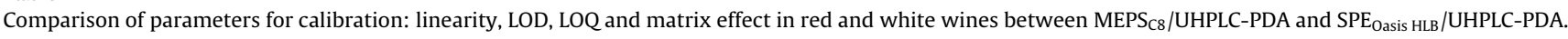

\begin{tabular}{|c|c|c|c|c|c|c|c|c|c|c|c|}
\hline \multirow{2}{*}{$\begin{array}{l}\text { Peak } \\
\text { number }\end{array}$} & \multirow[t]{2}{*}{ RT (min) } & \multirow[t]{2}{*}{$\lambda_{\max }{ }^{\mathrm{a}}(\mathrm{nm})$} & \multirow[t]{2}{*}{ Flavonols } & \multirow[t]{2}{*}{ Method } & \multirow{2}{*}{$\begin{array}{l}\text { Conc. Range } \\
\left(\mu \mathrm{g} \mathrm{mL}^{-1}\right)\end{array}$} & \multirow{2}{*}{$\begin{array}{l}\text { Regression } \\
\text { equation } \\
\left(y=a x^{\mathrm{b}}+b\right)\end{array}$} & \multirow[t]{2}{*}{$R^{2 \mathrm{c}}$} & \multirow{2}{*}{$\begin{array}{l}\text { LOD }^{\mathrm{d}} \\
\left(\mu \mathrm{g} \mathrm{mL}^{-1}\right)\end{array}$} & \multirow{2}{*}{$\begin{array}{l}\mathrm{LOQ}^{\mathrm{e}} \\
\left(\mu \mathrm{g} \mathrm{mL}^{-1}\right)\end{array}$} & \multicolumn{2}{|l|}{ Matrix effect ${ }^{\mathrm{f}}$} \\
\hline & & & & & & & & & & $\begin{array}{l}\text { Red wine } \\
( \pm \text { SD } \%)\end{array}$ & $\begin{array}{l}\text { White wine } \\
( \pm \text { SD } \%)\end{array}$ \\
\hline 1 & 4.420 & 372 & Myricetin & $\begin{array}{l}\text { MEPS }_{\mathrm{C} 8} \\
\text {MEPS }_{\mathrm{C} 8}\left(\mathrm{RW}^{\mathrm{g}}\right) \\
\mathrm{MEPS}_{\mathrm{C} 8}\left(\mathrm{WW}^{\mathrm{h}}\right) \\
\mathrm{SPE}_{\text {Oasis HLB }}\end{array}$ & $\begin{array}{l}0.1-5 \\
0.1-5 \\
0.1-5 \\
0.1-5\end{array}$ & $\begin{array}{l}0.0420 x-0.0156 \\
0.0415 x+0.1202 \\
0.0393 x+0.0233 \\
0.0136 x-0.0009\end{array}$ & $\begin{array}{l}0.9963 \\
0.9797 \\
0.9923 \\
0.9946\end{array}$ & 0.038 & $\begin{array}{l}0.042 \\
0.128\end{array}$ & $\begin{array}{l}1.01 \pm 7.5 \\
1.15 \pm 8.0\end{array}$ & $\begin{array}{l}1.07 \pm 5.9 \\
1.20 \pm 8.1\end{array}$ \\
\hline 2 & 4.731 & 360 & Quercetin & $\begin{array}{l}\text { MEPS }_{\mathrm{C} 8} \\
\text { MEPS }_{\mathrm{C} 8}(\mathrm{RW}) \\
\text { MEPS }_{\mathrm{C} 8}(\mathrm{WW}) \\
\mathrm{SPE}_{\text {Oasis HLB }}\end{array}$ & $\begin{array}{l}0.05-5 \\
0.05-5 \\
0.05-5 \\
0.05-5\end{array}$ & $\begin{array}{l}0.0810 x+0.0362 \\
0.0692 x+0.1889 \\
0.0718 x+0.0222 \\
0.0411 x+0.0066\end{array}$ & $\begin{array}{l}0.9966 \\
0.9603 \\
0.9400 \\
0.9815\end{array}$ & 0.010 & $\begin{array}{l}0.012 \\
0.032\end{array}$ & $\begin{array}{l}0.85 \pm 9.7 \\
1.03 \pm 9.5\end{array}$ & $\begin{array}{l}0.88 \pm 8.3 \\
0.92 \pm 7.3\end{array}$ \\
\hline 3 & 5.252 & 366 & Kaempferol & $\begin{array}{l}\text { MEPS }_{\mathrm{C} 8} \\
\text { MEPS }_{\mathrm{C} 8}(\mathrm{RW}) \\
\text { MEPS }_{\mathrm{C} 8}(\mathrm{WW}) \\
\text { SPE }_{\text {Oasis HLB }}\end{array}$ & $\begin{array}{l}0.05-3 \\
0.05-3 \\
0.05-3 \\
0.05-3\end{array}$ & $\begin{array}{l}0.0968 x+0.0215 \\
0.0932 x+0.0317 \\
0.0879 x+0.0233 \\
0.0344 x+0.0036\end{array}$ & $\begin{array}{l}0.9989 \\
0.9925 \\
0.9837 \\
0.9886\end{array}$ & $\begin{array}{l}0.011 \\
0.059\end{array}$ & $\begin{array}{l}0.037 \\
0.198\end{array}$ & $\begin{array}{l}0.96 \pm 11.2 \\
0.95 \pm 10.3\end{array}$ & $\begin{array}{l}0.90 \pm 6.4 \\
0.98 \pm 11.5\end{array}$ \\
\hline 4 & 5.524 & & Trolox (IS $\left.{ }^{\mathrm{i}}\right)$ & & & & & & & & \\
\hline $\begin{array}{ll}\text { a } & \text { Maxim } \\
\text { b } & x=\text { flav } \\
\text { c Correl } \\
\text { d Limit o } \\
\text { e Limit o } \\
\text { f Matrix } \\
\text { g RW: ca } \\
\text { h WW: c } \\
\text { i IS: inte }\end{array}$ & $\begin{array}{l}\text { im absorba } \\
\text { nol concent } \\
\text { ion coeffici } \\
\text { detection. } \\
\text { quantificat } \\
\text { ffect was c } \\
\text { ibration cur } \\
\text { libration cu } \\
\text { nal standar }\end{array}$ & $\begin{array}{l}\text { nce values ob } \\
\text { tration. } \\
\text { ent, give an e } \\
\text { ion. Values o } \\
\text { alculated by } \\
\text { rve in red wir } \\
\text { arve in white } \\
\text { d. }\end{array}$ & $\begin{array}{l}\text { tained in PDA } \\
\text { stimating how } \\
\text { tained from o } \\
\text { he quotient be } \\
\text { e. } \\
\text { wine. }\end{array}$ & $\begin{array}{l}\text { ystem detectio } \\
\text { well the experi } \\
\text { dinary least-sq } \\
\text { ween the slope }\end{array}$ & $\begin{array}{l}\text { ental points fi } \\
\text { res regressior } \\
\text { of the standar }\end{array}$ & $\begin{array}{l}\text { straight line. } \\
\text { data. } \\
\text { s in synthetic win }\end{array}$ & and spik & red and wh & wines. & & \\
\hline
\end{tabular}

through a $0.22 \mu \mathrm{m}$ membrane filters before injection into UHPLCPDA system. All extractions were carried out in triplicate, and each extract was injected three times.

\subsection{Validation of $M E P S_{C 8} / U H P L C$ method}

The newly developed MEPS $_{\mathrm{C} 8} / \mathrm{UHPLC}-\mathrm{DAD}$ approach was fully validated based on selectivity, linearity, limits of detection (LOD) and quantification (LOQ), inter- and intra-day precisions and accuracy. The assays were carried out using the $\mathrm{C} 8$ sorbent and a Waters Acquity $\mathrm{H}$-Class equipped with a $100 \mathrm{~mm} \times 1.8 \mu \mathrm{m}$ UPLC analytical column.

The selectivity of the method was assessed by the absence of interfering peaks at the retention time of target flavonols. The linearity was evaluated building three calibration curves (peak

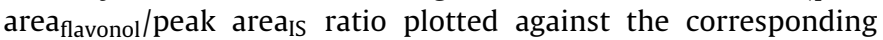
standard concentration) for each flavonol using standards prepared in synthetic wine, at 7 different concentrations levels, including the zero point (Table 1 ). The zero point (not spiked synthetic wine) enables to verify that none of the compounds showed residual level or background signal. Each level of concentration was prepared in triplicate and injected three times, so there were a total of nine replicates.

The sensitivity was assessed by determining the LOD (the lowest analyte concentration that produces a response detectable above the noise level of the system) and LOQ (the lowest level of analyte that can be accurately and precisely measured) for each compound. LOD and LOQ were calculated with the data generated in the linearity studies, being LOD defined as $\left(a+3 S_{a / b}\right)$ and LOQ as $\left(a+10 S_{a / b}\right)$, where " $a$ " represents origin ordinate, " $S_{a}$ " the origin ordinate variance and " $b$ " the slope [59]. These parameters were calculated for each analyte from the standard solutions used to obtain the corresponding calibration curves, using the UHPLC developed method.

To check the accuracy of the proposed method a recovery study was carried out by spiking a red wine (RW\#3) and a white wine (WW\#26), in triplicate at two concentration levels corresponding to the LL (low level, lowest concentration of calibration curve) and HL (high level, highest concentration of calibration curve), and subjected to the MEPS $\mathrm{C}_{\mathrm{C}}$ procedure described above. The recovery values were calculated according to the Eq. (1).

Accuracy $=100 \times\left\{\frac{\left([\text { flavonol }]_{\text {after spiking }}-[\text { flavonol }]_{\text {before spiking }}\right)}{[\text { flavonol }]_{\text {added }}}\right\}$

where [flavonol $]_{\text {after spiking }}$ is the flavonol concentration measured

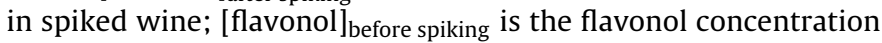
measured in unspiked wine, and [flavonol $]_{\text {added }}$ is the nominal concentration of the flavonol added to wine.

Method precision (expressed as relative standard deviation, RSD \%) was tested by spiking a synthetic wine at three different concentration levels, corresponding to the low level (LL), medium level (ML) and highest point (HL) of calibration curve of each target flavonol and treated by MEPS ${ }_{\mathrm{C} 8}$. Seven replicates $(n=7)$ were performed in the same day to obtain repeatability (intra-day precision, $\mathrm{RSD}_{\mathrm{r}} \%$ ). For inter-day precision (reproducibility, $\mathrm{RSD}_{\mathrm{R}}, \%$ ) evaluation, the same protocol was followed but six replicates of each level were analyzed daily through three different days $(n=18)$.

The matrix effect was evaluated by the quotient between the slopes of the standards in "blank" matrix (synthetic wine) and those obtained by spiking RW\#3 and WW\#26 wines (standard addition method).

\section{Results and discussion}

To enable a high throughput, robust and accurate method for quantification of flavonols in wines, a MEPS approach combined with UHPLC-PDA system was developed. Their performance was compared with the SPE technique using Oasis HLB as sorbent.

The extracts were monitored at four different wavelengths, $375,371,366$ and $289 \mathrm{~nm}$, corresponding to maximum absorbance wavelength of myricetin, quercetin, kaempferol and Trolox (IS), respectively. They were identified by comparing the retention time and spectral characteristics of their peaks with those of standards (Fig. 1S; Supplementary figure) and quantified using the standards 

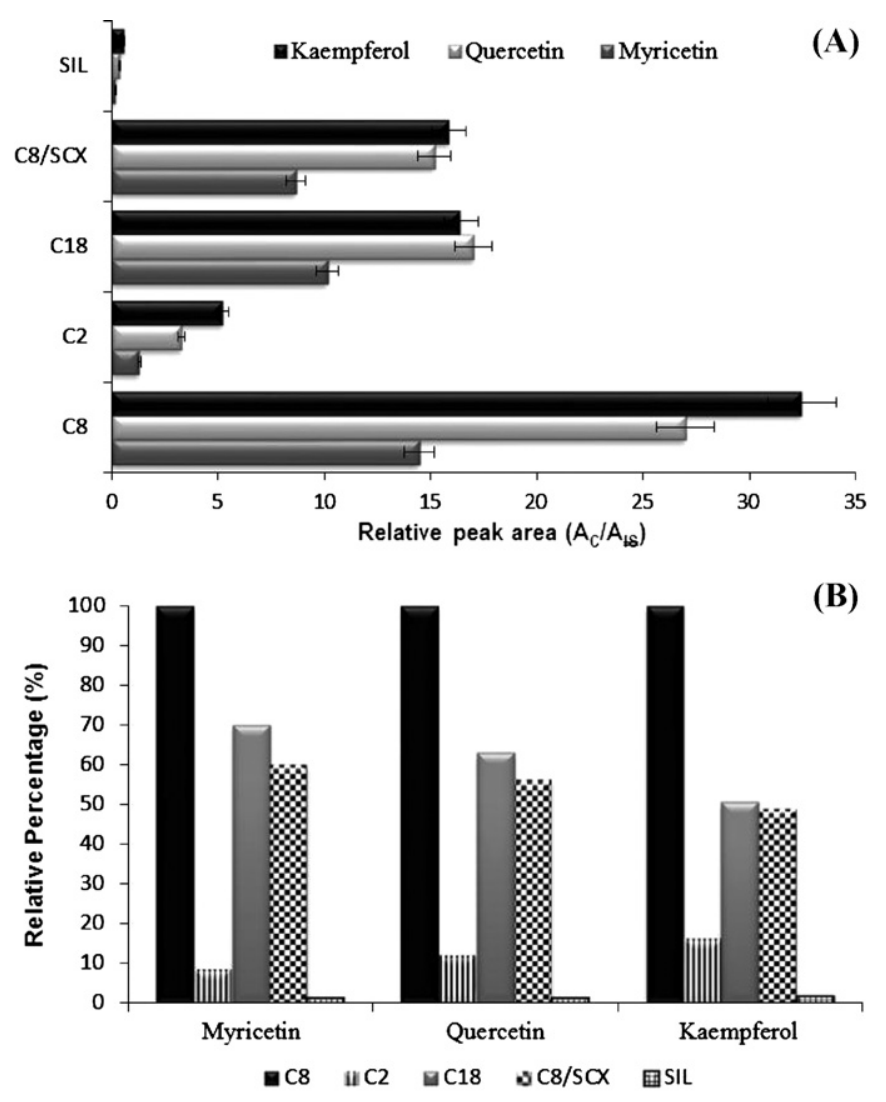

Fig. 2. (A) Comparison the performance characteristics (relative peak areas obtained for each adsorbent) of different MEPS adsorbents for isolation of target flavonols from wines; and (B) normalized extraction efficiencies measured for C2, C8, C18, SIL and $\mathrm{C} 8 / \mathrm{SCX}$.

of each one.Supplementary material related to this article found, in the online version, at http://dx.doi.org/10.1016/j.aca.2012.06.020.

\subsection{MEPS optimization}

The development of the MEPS procedure for the analysis of flavonols involved consideration and optimization of the following factors: nature of the adsorbent, number of extraction cycles, elution volume, sample volume, and ethanol content. Experiments to evaluate these factors were conducted using synthetic wine mixtures of flavonols.

\subsubsection{Nature of sorbent}

The selection of an appropriate sorbent is of major importance to achieve acceptable clean-up and extraction yield [60]. Five different MEPS sorbents namely the silica-based C2, C8 and C18 phases (suitable for lipophilic analytes), as well as the mixed bonded silica C8/SCX (suitable for polar analytes such as acidic and basic compounds) containing both reversed phase and cationic exchange groups, and the polar silica phase (SIL), were tested. Fig. 2A shows the UHPLC-PDA response for the target analytes using different sorbents.

The performance of each commercially available MEPS adsorbent was evaluated in terms of intensity of the response observed (relative peak area) and reproducibility. It was observed that the C8 sorbent exhibits better extraction efficiency for all target flavonols, as demonstrated by the highest UHPLC-PDA responses (based on peak area) (Fig. 2A). On the other hand SIL sorbent showed the lowest performance. The use of $\mathrm{C} 8 / \mathrm{SCX}$ phase did not induce high response, indicating that the sulfonyl groups of the phase did not play a role in the retention of flavonols. Therefore, the C8 sorbent was used in subsequent method optimization stages. The sum of the target flavonols peak areas obtained for each sorbent was normalized in relation to the sum of the flavonols peak areas obtained for the $\mathrm{C} 8$ sorbent. The extraction efficiency was calculated for each sorbent, and the results are presented in Fig. 2B. In the case of the C8 sorbent, this study illustrated excellent extraction efficiencies for all compounds studied (Fig. 2B), thus supporting the conclusion that the $\mathrm{C} 8$ approach provides the best extraction efficiency for the purposes of this research.

The effect of $\mathrm{pH}$ on the $\mathrm{C} 8$ sorbent partition mechanism was evaluated by adjust the sample $\mathrm{pH}$, prior to extraction, to $\mathrm{pH} 3.4,5$, 7 and 9 (using diluted hydrochloric acid solution or dilute sodium hydroxide solution). The stability of flavonols is influenced by $\mathrm{pH}$ being stable in strongly acidic conditions. The optimum $\mathrm{pH}$ for the analysis of the target flavonols was found to be pH 3.4 (Supplementary Fig. 2S).Supplementary material related to this article found, in the online version, at http://dx.doi.org/10.1016/j.aca.2012.06.020.

\subsubsection{Number of extraction cycles and volume of sample}

In MEPS the retention on the sorbent phase is affected by the number of extraction cycles performed and by the elution flow rate (about $20 \pm 2.3 \mu \mathrm{Ls}^{-1}$, on average). The sample can be drawn through the needle into the syringe up and down, once or several times (cycles) without discarding it. Fig. 3A shows the effect of the number of extraction cycles (1, 5 and 10, extract-discard) and the impact of sample volume $(50,100$ and $250 \mu \mathrm{L})$ on the extraction efficiency of flavonols. Assays showed that the competition for active adsorption sites of the C8 sorbent increased slightly as the applied extraction number and sample volume increased (Fig. 3A and B), thereby increasing extraction efficiency of MEPS $\mathrm{C}_{\mathrm{C}}$. Secondly, the volume of sample was optimized. $250 \mu \mathrm{L}$ of wine sample was the optimal volume (Fig. $3 \mathrm{~A}$ ) required to recover the target flavonols without any further dilution of the extract. Small sample volumes given rise to increasing extraction cycles (extractdiscard cycles) and furthermore increase the extraction amount in unit volume of sample of organic solvent. Statistically, no significant differences were observed when $250 \mu \mathrm{L}$ of synthetic wine sample are passed through the $\mathrm{C} 8$ sorbent once, five and ten times. For this reason $5 \times 250 \mu \mathrm{L}$ was selected, since the results showed that five extraction cycles gave a good recovery and can extend the lifetime of the MEPS cartridge. Similar outcomes were concluded by Zhang et al. [61] in their studies associated with the optimization of condition for analysis of five estrogens in urine and milk.

\subsubsection{Elution volume}

The extraction performances by different elution volumes namely $50 \mu \mathrm{L}, 100 \mu \mathrm{L}, 250 \mu \mathrm{L}, 350 \mu \mathrm{L}$, and $500 \mu \mathrm{L}$ of methanol/water $0.1 \%$ formic acid $(80: 20)$ solution, were compared. The results in Fig. 3B indicated that the extraction efficiencies were enhanced by decreasing volume of elution solution. On the other hand a complex matrix such as wines can saturate the adsorbent phase and the partitioning may be hindered by interferences. For the wine flavonols extraction the optimal recovery (Fig. 3B) was obtained when $50 \mu \mathrm{L}$ of elution solution containing $80 \%$ of methanol and $20 \%$ aqueous solution of formic acid was used.

\subsection{MEPS performance. Comparison with $S P E_{O a i s ~}^{H L B}$}

To demonstrate the feasibility of the present approach for determination of wine flavonols and to evaluate their practical applicability, the method was fully validated considering the selectivity, linearity, LOD, LOQ, intra/inter-day precision, accuracy and matrix effects. Their performance was compared with a previously $\mathrm{SPE}_{\text {Oais HLB }}$ validated method in our laboratory by Silva et al. [43]. The validation parameters are shown in Table 1 . 

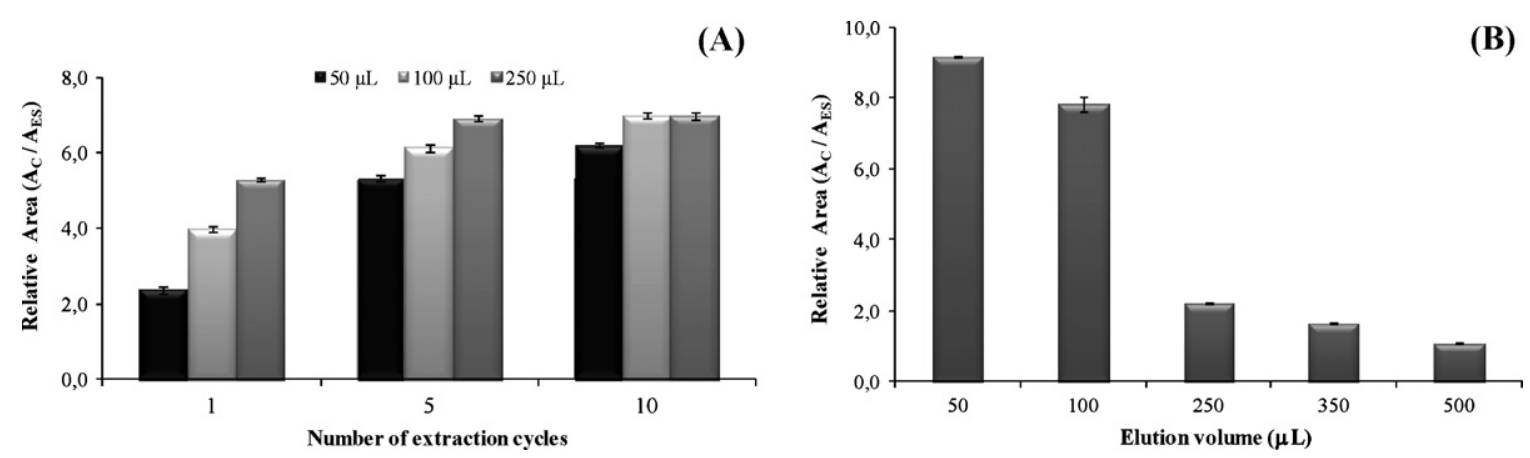

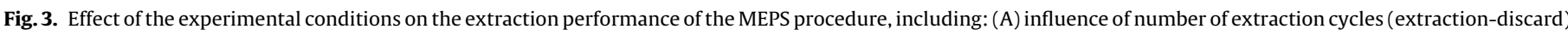

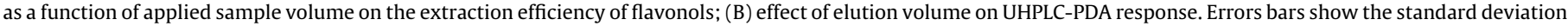
of the mean $(n=3)$.

Table 2

Recovery (\%) of flavonols added to each of two wines at high concentration (HL) and low concentration (LL) level. ${ }^{\mathrm{a}}$

\begin{tabular}{|c|c|c|c|c|c|c|c|c|c|c|}
\hline \multirow[t]{2}{*}{ Flavonol } & \multicolumn{4}{|l|}{ MEPS $_{\mathrm{C} 8}$} & \multirow{2}{*}{$\begin{array}{l}\text { Overall } \\
\text { mean } \pm S D\end{array}$} & \multicolumn{4}{|l|}{$\mathrm{SPE}_{\text {Oasis HLB }}$} & \multirow{2}{*}{$\begin{array}{l}\text { Overall } \\
\text { mean } \pm S D\end{array}$} \\
\hline & $\mathrm{RW}_{\mathrm{LL}}{ }^{\mathrm{b}}$ & $\mathrm{RW}_{\mathrm{HL}}{ }^{\mathrm{c}}$ & $\mathrm{WW}_{\mathrm{LL}}{ }^{\mathrm{d}}$ & $\mathrm{WW}_{\mathrm{HL}}{ }^{\mathrm{e}}$ & & $\mathrm{RW}_{\mathrm{LL}}$ & $\mathrm{RW}_{\mathrm{HL}}$ & $\mathrm{WW}_{\mathrm{LL}}$ & $\mathrm{WW}_{\mathrm{HL}}$ & \\
\hline Myricetin $^{\mathrm{f}}$ & $90.6 \pm 1.6$ & $93.2 \pm 0.8$ & $94.1 \pm 0.4$ & $88.6 \pm 0.2$ & $91.6 \pm 0.7$ & $85.0 \pm 8.4$ & $111.0 \pm 5.3$ & $89.0 \pm 5.6$ & $99.0 \pm 1.1$ & $96.0 \pm 4.7$ \\
\hline Querceting & $83.0 \pm 0.8$ & $87.2 \pm 0.9$ & $89.2 \pm 0.8$ & $84.5 \pm 1.2$ & $85.9 \pm 0.9$ & $104.0 \pm 9.2$ & $102 \pm 6.9$ & $78.0 \pm 5.0$ & $89.2 \pm 4.9$ & $93.2 \pm 6.0$ \\
\hline Kaempferol $^{\mathrm{h}}$ & $92.5 \pm 1.3$ & $97.0 \pm 0.5$ & $88.9 \pm 0.3$ & $90.1 \pm 0.1$ & $92.1 \pm 0.5$ & $82.0 \pm 7.5$ & $76 \pm 8.0$ & $89 \pm 4.6$ & $102 \pm 3.1$ & $87.2 \pm 5.5$ \\
\hline
\end{tabular}

a Each wine was assayed three times before and after each addition, and average of results is presented.

b $\mathrm{RW}_{\amalg}$ red wine fortified with flavonols at low concentration level.

c $\mathrm{RW}_{\mathrm{HL}}$ red wine fortified with flavonols at high concentration level.

d $W_{\mathrm{LL}}$ white wine fortified with flavonols at low concentration level.

e $\mathrm{WW}_{\mathrm{HL}}$ white wine fortified with flavonols at high concentration level.

${ }^{f}$ Myricetin: $\mathrm{LL}=0.2 \mu \mathrm{g} \mathrm{mL}{ }^{-1} ; \mathrm{HL}=4.0 \mu \mathrm{g} \mathrm{mL}^{-1}$.

g Quercetin: $\mathrm{LL}=0.1 \mu \mathrm{g} \mathrm{mL} \mathrm{m}^{-1} ; \mathrm{HL}=4.0 \mu \mathrm{g} \mathrm{mL}^{-1}$.

h Kaempferol: $\mathrm{LL}=0.1 \mu \mathrm{g} \mathrm{mL} \mathrm{m}^{-1} ; \mathrm{HL}=3.0 \mu \mathrm{g} \mathrm{mL}^{-1}$.

For each flavonol a linear regression of the peak area flavonol $_{\text {peak }}$ area $_{\text {IS }}$ vs concentration, was calculated to determine the linearity of the method using three replicates at seven levels of concentration (Table 1).

The UHPLC-PDA system gave linear response over the studied range of concentrations and the least-squares linear regression analysis of the data provided excellent correlation coefficient $\left(R^{2}\right)$ values for all compounds tested with $R^{2}>0.9963$ for MEPS and $R^{2}>0.9815$ for SPE $E_{\text {Oasis HLB }}$ method, over synthetic wine, and residuals not exceeding $\pm 6.3 \%$.

The LOD and LOQ were calculated from ordinary least-squares regression data [62]. The standard deviation chosen to calculate the LOD and LOQ values is the residual standard deviation of the regression line for all flavonols in the analyzed matrix. The MEPS $_{\mathrm{C} 8} / \mathrm{UHLPC}-\mathrm{PDA}$ methodology gave in general very low detection limits, ranging between 0.006 (quercetin) and $0.013 \mu \mathrm{g} \mathrm{mL}^{-1}$ (myricetin), while limits of quantification were in the range
$0.012-0.042 \mu \mathrm{g} \mathrm{mL}^{-1}$, for quercetin and myricetin, respectively

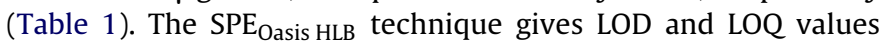
slightly higher than the developed $\left(\mathrm{MEPS}_{\mathrm{C8}}\right)$ technique.

The matrix effect was evaluated through the coefficient between the calibration curve obtained with standards in synthetic wine and those obtained from spiked RW\#3 and WW\#26 wines (standard addition method). Matrix effect values ranged from $0.85 \pm 9.7$ (quercetin) to $0.11 \pm 5.9 \%$ (myricetin) with an average value of $0.99 \%$ for $\mathrm{MEPS}_{\mathrm{C} 8}$ technique. Regarding $\mathrm{SPE}_{\text {Oasis HLB }}$ procedure, the average values of matrix effect was found to be similar, $0.99 \%$ on average, with the individual values ranging between $0.92 \pm 7.3$ and $1.2 \pm 8.1 \%$. Therefore no significant matrix effect was observed (Table 1).

The recovery studies were carried out by spiking RW\#3 and WW\#26 wine samples at two concentration levels (LL and HL), with a known amount of each flavonol (Table 2). The concentration of phenolics added to the wines was chosen to cover the expected

Table 3

Precision $^{\mathrm{a}}$ of $\mathrm{MEPS}_{\mathrm{C} 8} / \mathrm{UHPLC}-\mathrm{PDA}$ and $\mathrm{SPE}_{\mathrm{Oasis} \mathrm{HLB}} / \mathrm{UHPLC}-\mathrm{PDA}$ assays for the target flavonols.

\begin{tabular}{|c|c|c|c|c|c|c|c|c|c|c|c|c|c|c|c|c|}
\hline \multirow[t]{2}{*}{ Flavonol } & \multicolumn{4}{|c|}{$\begin{array}{l}\text { MEPS }_{C 8} \\
\text { Intra-day precision }(n=7)\end{array}$} & \multicolumn{4}{|c|}{ Inter-day precision $(n=18)$} & \multicolumn{4}{|c|}{$\begin{array}{l}\mathrm{SPE}_{\text {Oasis HLB }} \\
\text { Intra-day precision }(n=7)\end{array}$} & \multicolumn{4}{|c|}{ Inter-day precision $(n=18)$} \\
\hline & LL & ML & $\mathrm{HL}$ & $\begin{array}{l}\text { Overall mean } \\
( \pm \mathrm{SD} \%)\end{array}$ & LL & ML & $\mathrm{HL}$ & $\begin{array}{l}\text { Overall mean } \\
( \pm \mathrm{SD} \%)\end{array}$ & LL & ML & $\mathrm{HL}$ & $\begin{array}{l}\text { Overall mean } \\
( \pm \text { SD } \%)\end{array}$ & LL & ML & $\mathrm{HL}$ & $\begin{array}{l}\text { Overall mean } \\
( \pm \mathrm{SD} \%)\end{array}$ \\
\hline Myricetin $^{\mathrm{b}}$ & 3.1 & 1.5 & 0.9 & $1.8 \pm 1.1$ & 1.3 & 1.8 & 1.4 & $1.5 \pm 0.3$ & 7.8 & 3.6 & 2.9 & $4.8 \pm 2.7$ & 6.3 & 5.9 & 4.2 & $5.5 \pm 1.1$ \\
\hline Quercetin $^{c}$ & 2.2 & 0.8 & 0.7 & $1.2 \pm 0.8$ & 2.8 & 0.7 & 0.9 & $1.5 \pm 1.2$ & 4.6 & 1.9 & 1.1 & $2.5 \pm 1.8$ & 7.1 & 8.9 & 2.6 & $6.2 \pm 3.2$ \\
\hline Kaempferol $^{\mathrm{d}}$ & 1.4 & 0.5 & 0.9 & $0.9 \pm 0.5$ & 1.6 & 1.2 & 0.6 & $1.1 \pm 0.5$ & 3.7 & 1.7 & 0.3 & $1.9 \pm 1.7$ & 4.7 & 3.2 & 4.1 & $4.0 \pm 0.8$ \\
\hline
\end{tabular}

a Synthetic wine spiked with flavonols; at high concentration level.

b Myricetin: $\mathrm{LL}=0.2 \mu \mathrm{g} \mathrm{mL}{ }^{-1} ; \mathrm{ML}=1.4 \mu \mathrm{g} \mathrm{mL}^{-1} ; \mathrm{HL}=5.0 \mu \mathrm{g} \mathrm{mL}^{-1}$.

c Quercetin: $\mathrm{LL}=0.1 \mu \mathrm{g} \mathrm{mL}^{-1} ; \mathrm{ML}=2.0 \mu \mathrm{g} \mathrm{mL}^{-1} ; \mathrm{HL}=5.0 \mu \mathrm{g} \mathrm{mL}^{-1}$.

${ }^{\mathrm{d}}$ Kaempferol: $\mathrm{LL}=0.1 \mu \mathrm{g} \mathrm{mL}{ }^{-1} ; \mathrm{ML}=0.8 \mu \mathrm{g} \mathrm{mL}^{-1} ; \mathrm{HL}=3.0 \mu \mathrm{g} \mathrm{mL}^{-1}$. 


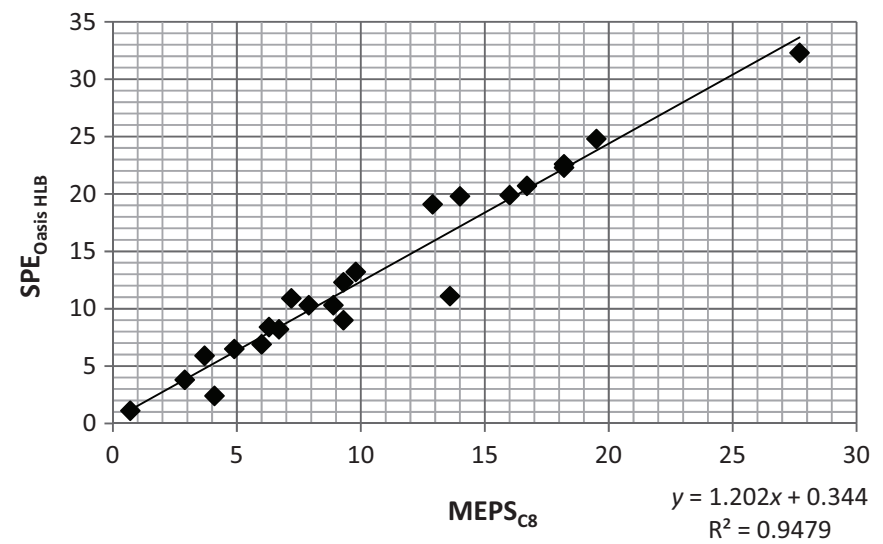

Fig. 4. Correlation between the $\mathrm{MEPS}_{\mathrm{C} 8}$ and $\mathrm{SPE}_{\mathrm{Oasis} \mathrm{HLB}}$ extraction techniques for isolation the target wine flavonols.

values in the wine samples. The accuracy was determined according to the equation presented in Section 2.4. The obtained values for each fortification level are listed in Table 2 .

At all concentration levels, satisfactory results were found with recovery values ranging from $83.0 \pm 0.8\left(\mathrm{RW}_{\mathrm{LL}}\right)$ to $97.0 \pm 0.5 \%$ $\left(\mathrm{RW}_{\mathrm{HL}}\right)$, and between $82.0 \pm 7.5\left(\mathrm{RW}_{\mathrm{LL}}\right)$ and $111.0 \pm 5.3 \%\left(\mathrm{RW}_{\mathrm{HL}}\right)$, for $\mathrm{MEPS}_{\mathrm{CB}}$ and $\mathrm{SPE}_{\mathrm{Oasis} \mathrm{HLB}}$, respectively. At low flavonols concentration (LL), the extraction yields were slightly lower than that obtained at high concentration level (HL). The fact that the sorbent's chemistry surface can be changed by interfering compounds from wine, which therefore can change the sorption properties may explain this observation [52]. This effect is more pronounced at low concentrations of the analyte when analyte/matrix ratio is very low. The same behavior was observed for accuracy.

The precision was measured through inter-day reproducibility and intra-day repeatability studies, expressed by the RSD\% and calculated using the measurement of relative peak area of each flavonol in the matrix. The repeatability was measured by comparing standard deviation of spiked synthetic wine (LL, ML, HL) run in the same day $(n=7)$. The reproducibility was determined by analyzing spiked synthetic wine samples for three alternate days. The results are satisfactory with RSD values lower than 3.1\% for each measured analyte at all spiking levels (Table 3 ). The repeatability values at the three different levels ranged from 0.5 (kaempferol at ML concentration) to $2.2 \%$ (quercetin at LL concentration) $(n=7)$, whereas the reproducibility varied from 0.6 (kaempferol at HL concentration) to $1.3 \%$ (quercetin at LL concentration).

Combination of fast MEPS technique together with quick UHPLC-PDA system proves to be an improved strategy, with excellent recoveries, sensitivity, and repeatability, which make it possible to use as a quick approach to analyze the selected biological active constituents in wines.

\subsection{Determination of flavonols in wines by $M E P S_{C 8}$ and $S P E_{\text {Oasis } H L B}$}

In order to test the applicability of the developed method, MEPS procedure was first applied to a mixture of flavonols standards and then to thirty wine samples (22 red and 8 white wines) (Table 4). In addition, the proposed method was compared with SPE $\mathrm{Oasis} \mathrm{HLB}$ technique. The correlation between the two sampling methods is provided by the results given in Fig. 4. It shows the plot of the MEPS $_{\mathrm{C} 8} /$ UHLPC-PDA data against SPE Oasis HLB $_{\text {UHLPC-PDA data for }}$ the 30 studied wines.

As can be seen, the values obtained with both techniques are well correlated $\left(R^{2}=0.9479\right)$, which means that in terms of quantification, both methods can be used. However, several other
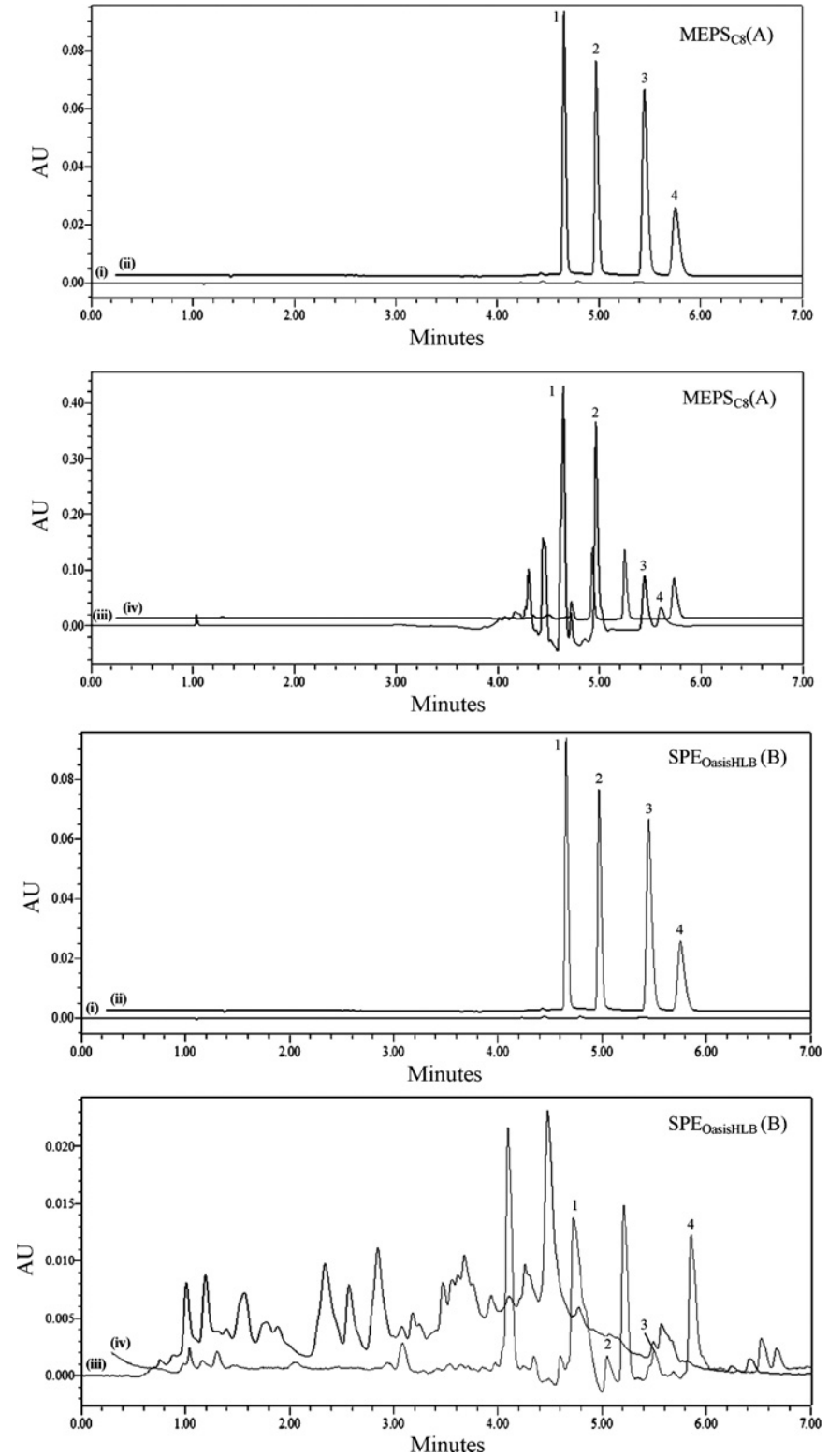

Fig. 5. Comparison of the wine flavonols UHPLC-PDA profile measured at maximum wavelength of each flavonol (See Table 1), after extracted with: (A) optimized MEPS $_{\mathrm{C8}}$ - (i) synthetic wine (selectivity); (ii) synthetic wine spiked with flavonols;

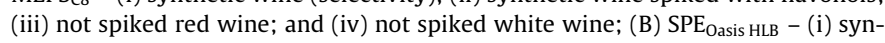
thetic wine (selectivity); (ii) synthetic wine spiked with flavonols; (iii) not spiked red wine; and (iv) not spiked white wine; (for peak identification see Table 1).

experimental parameters should be taking into account, such as the extraction efficiency, the extraction time, solvent consumption, fast sample throughput, among others. In this regard MEPS technique offers advantages than SPE.

The resulting chromatograms of both methods are shown in Fig. 5. The separation of the target flavonols is very fast, being achieved within only $7 \mathrm{~min}$.

Accurate quantification and improved sensitivities for all three flavonols analysis in red and white wines were achieved by $\mathrm{MEPS}_{\mathrm{C} 8}$ (Fig. 5A). In addition, the chromatographic profile resulting from MEPS $_{\mathrm{C} 8}$ extracts is much cleaner than that obtained by SPE (Fig. 5B), meaning that the selectivity of Oasis HLB sorbent towards flavonols is poorer tha C8 sorbent. The chromatograms obtained for white and red wines samples showed quite different profiles and their complexity increases or decreases according to the 
Table 4

Flavonol composition ${ }^{\mathrm{a}}$ of representative commercial wines ( $\mu \mathrm{g} \mathrm{mL} \mathrm{L}^{-1}$ ) (flavonol data have been corrected for recoveries).

\begin{tabular}{|c|c|c|c|c|c|c|c|c|c|c|c|}
\hline \multirow[t]{2}{*}{ Wine sample } & \multirow[t]{2}{*}{ Vintage } & \multirow[t]{2}{*}{ Varieties } & \multicolumn{2}{|l|}{ Myricetin } & \multicolumn{2}{|l|}{ Quercetin } & \multicolumn{2}{|c|}{ Kaempferol } & \multicolumn{2}{|c|}{ Total flavonols } & \multirow[t]{2}{*}{$\Delta_{\text {flavonols }}$} \\
\hline & & & MEPS & SPE & MEPS & SPE & MEPS & SPE & MEPS & SPE & \\
\hline \multicolumn{12}{|l|}{ Red wines (RW) } \\
\hline \#1 & 2008 & $\begin{array}{l}\text { Tinta Barroca, Tinta Roriz, } \\
\text { Touriga Franca }\end{array}$ & $7.2 \pm 1.6$ & $6.6 \pm 1.5$ & n.d. ${ }^{b}$ & $4.3 \pm 1.2$ & $<\mathrm{LOQ}^{\mathrm{c}}$ & n.d. & 7.2 & 10.9 & 3.7 \\
\hline \#2 & $N A^{d}$ & Syrah, Castelão and Aragonez & $8.9 \pm 3.2$ & $8.7 \pm 3.5$ & n.d. & n.d. & $0.4 \pm 0.01$ & $0.3 \pm 0.1$ & 9.3 & 9.0 & -0.3 \\
\hline \#3 & 2010 & $\begin{array}{l}\text { Aragonez, Trincadeira and } \\
\text { Castelão }\end{array}$ & n.d. & n.d. & n.d. & n.d. & n.d. & n.d. & - & - & - \\
\hline$\# 4$ & 2010 & Syrah, Trincadeira and Castelão & $6.4 \pm 1.2$ & $8.0 \pm 0.9$ & n.d. & n.d. & $0.3 \pm 0.4$ & $0.2 \pm 0.09$ & 6.7 & 8.2 & 1.5 \\
\hline \#5 & 2009 & Touriga Nacional and Castelão & $8.7 \pm 0.7$ & $10.3 \pm 1.4$ & n.d. & n.d. & $0.2 \pm 0.1$ & n.d. & 8.9 & 10.3 & 1.4 \\
\hline \#6 & 2007 & $\begin{array}{l}\text { Touriga Nacional, Alfrocheiro } \\
\text { and Tinta Roriz }\end{array}$ & $13.4 \pm 0.6$ & $16.1 \pm 1.0$ & n.d. & n.d. & $4.8 \pm 0.9$ & $6.2 \pm 1.0$ & 18.2 & 22.3 & 4.1 \\
\hline \#7 & 2008 & $\begin{array}{l}\text { Castelão, Aragonez and } \\
\text { Trincadeira }\end{array}$ & $2.9 \pm 0.5$ & $3.8 \pm 1.3$ & n.d. & n.d. & n.d. & n.d. & 2.9 & 3.8 & 0.9 \\
\hline$\# 8$ & 2008 & $\begin{array}{l}\text { Touriga Nacional, Touriga } \\
\text { Francesa, Tinta Roriz and Tinta } \\
\text { Barroca }\end{array}$ & $5.6 \pm 1.1$ & $6.6 \pm 2.6$ & n.d. & n.d. & $0.4 \pm 0.1$ & $0.3 \pm 0.07$ & 6.0 & 6.9 & 0.9 \\
\hline$\# 9$ & 2009 & Rufete, Marufo and Tinta Roriz & $12.4 \pm 1.7$ & $14.2 \pm 3.2$ & $4.1 \pm 1.2$ & $6.4 \pm 1.7$ & $0.2 \pm 0.9$ & $0.1 \pm 0.06$ & 16.7 & 20.7 & 4.0 \\
\hline \#10 & 2010 & Castelão & $5.8 \pm 0.1$ & $8.1 \pm 0.8$ & n.d. & n.d. & $0.5 \pm 0.4$ & $0.3 \pm 0.1$ & 6.3 & 8.4 & 2.1 \\
\hline \#11 & 2009 & $\begin{array}{l}\text { Touriga Nacional and Tinta } \\
\text { Roriz }\end{array}$ & $10.7 \pm 2.2$ & $13.2 \pm 2.9$ & $3.3 \pm 0.4$ & $6.6 \pm 0.8$ & $<\mathrm{LOQ}$ & n.d. & 14.0 & 19.8 & 5.8 \\
\hline \#12 & 2009 & $\begin{array}{l}\text { Aragonez, Tincadeira and } \\
\text { Alicante }\end{array}$ & $2.9 \pm 0.2$ & $3.4 \pm 0.7$ & $5.2 \pm 2.2$ & $7.4 \pm 1.4$ & $1.7 \pm 0.41$ & $2.4 \pm 0.8$ & 9.8 & 13.2 & 3.4 \\
\hline \#13 & 2009 & $\begin{array}{l}\text { Aragonez, Trincadeira, } \\
\text { Cabernet }\end{array}$ & $16.8 \pm 2.5$ & $15.7 \pm 2.7$ & $7.5 \pm 1.8$ & $10.6 \pm 1.5$ & $3.4 \pm 0.6$ & $6.0 \pm 2.6$ & 27.7 & 32.3 & 4.6 \\
\hline$\# 14$ & 2009 & Baga and Touriga Nacional & $3.9 \pm 1.4$ & $6.3 \pm 2.9$ & $0.4 \pm 0.1$ & $0.2 \pm 0.1$ & $0.6 \pm 0.2$ & $<$ LOQ & 4.9 & 6.5 & 1.6 \\
\hline \#15 & 2007 & Tinta Negra Mole & $4.1 \pm 0.7$ & $2.4 \pm 0.9$ & n.d. & n.d. & $<$ LOQ & n.d. & 4.1 & 2.4 & -1.7 \\
\hline \#16 & 2009 & $\begin{array}{l}\text { Tinta Roriz and Touriga } \\
\text { Nacional }\end{array}$ & $4.3 \pm 0.5$ & $6.6 \pm 1.6$ & $2.2 \pm 0.7$ & $4.4 \pm 0.8$ & $2.8 \pm 1.7$ & $1.3 \pm 0.8$ & 9.3 & 12.3 & 3 \\
\hline$\# 17$ & 2006 & Bastardo and Touriga National & $5.7 \pm 0.8$ & $2.9 \pm 1.3$ & $9.3 \pm 4.4$ & $11.1 \pm 1.8$ & $3.2 \pm 0.9$ & $7.3 \pm 1.0$ & 18.2 & 22.6 & 4.4 \\
\hline \#18 & 2008 & NA & $13.1 \pm 4.5$ & $15.0 \pm 3.4$ & $2.8 \pm 1.3$ & $4.9 \pm 0.4$ & $0.8 \pm 4.5$ & n.d. & 16.0 & 19.9 & 3.9 \\
\hline \#19 & 2009 & $\begin{array}{l}\text { Merlot, Cabernet Sauvignon, } \\
\text { Saborinho }\end{array}$ & $10.4 \pm 2.8$ & $5.7 \pm 2.8$ & $3.2 \pm 0.9$ & $5.4 \pm 2.6$ & $<$ LOQ & n.d. & 13.6 & 11.1 & -2.5 \\
\hline \#20 & 2010 & Merlot, Cabernet and Syrah & $7.8 \pm 1.7$ & $5.3 \pm 1.7$ & $11.0 \pm 3.4$ & $19.2 \pm 3.5$ & $0.7 \pm 0.3$ & $0.3 \pm 0.2$ & 19.5 & 24.8 & 5.3 \\
\hline \#21 & 2009 & Periquita and Saborinho & $7.9 \pm 0.8$ & $10.3 \pm 3.3$ & n.d. & n.d. & $<$ LOQ & n.d. & 7.9 & 10.3 & 2.4 \\
\hline$\# 22$ & 2010 & Agronómica and Saborinho & $4.1 \pm 0.2$ & $3.2 \pm 0.6$ & $7.9 \pm 3.3$ & $14.3 \pm 0.2$ & $0.9 \pm 2.4$ & $1.6 \pm 1.9$ & 12.9 & 19.1 & 6.2 \\
\hline \multicolumn{12}{|c|}{ White wines (WW) } \\
\hline \#23 & 2009 & NA & n.d. & n.d. & n.d. & n.d. & n.d. & n.d. & n.d. & n.d. & n.d. \\
\hline$\# 24$ & 2010 & Rabo-de-ovelha & n.d. & n.d. & $3.4 \pm 1.7$ & $5.8 \pm 1.6$ & $0.3 \pm 0.1$ & $0.1 \pm 0.06$ & 3.7 & 5.9 & 2.2 \\
\hline$\# 25$ & 2009 & $\begin{array}{l}\text { Roupeiro, Antão Vaz and } \\
\text { Perrum }\end{array}$ & n.d. & n.d. & n.d. & n.d. & n.d. & n.d. & n.d. & n.d. & n.d. \\
\hline \#26 & 2009 & Antão Vaz and Roupeiro & n.d. & n.d. & n.d. & n.d. & n.d. & n.d. & n.d. & n.d. & n.d. \\
\hline \#27 & 2010 & Malvasia Fina and Gouveio & n.d. & n.d. & $<$ LOQ & n.d. & n.d. & n.d. & n.d. & n.d. & n.d. \\
\hline \#28 & 2010 & Moscatel and Arinto & n.d. & n.d. & $<$ LOQ & n.d. & n.d. & n.d. & n.d. & n.d. & n.d. \\
\hline$\# 29$ & 2009 & $\begin{array}{l}\text { Encruzado, Bical and Malvasia } \\
\text { Fina }\end{array}$ & n.d. & n.d. & n.d. & n.d. & n.d. & n.d. & n.d. & n.d. & n.d. \\
\hline \#30 & 2010 & NA & n.d & n.d. & n.d. & n.d. & n.d. & $1.10 \pm 1.1$ & 0.7 & 1.1 & 0.4 \\
\hline
\end{tabular}

a The content of each of the flavonols analyzed in the wine samples tested is the mean of three replicates \pm SD and indicated as $\mu \mathrm{g} \mathrm{mL}^{-1}$.

b n.d.: not detected.

c <LOQ: lower than quantification limit.

d NA: data not available.

wavelength. The maximum absorbance wavelength of each flavonol, listed in Table 1, was used for quantification purposes.

The content of the target flavonols found in the assayed wines is summarized in Table 4. As can be observed, the concentration of flavonols in investigated red wines is significantly higher than the concentrations determined in white wines. The fact that the polyphenols content in red wines is higher than white wines was widely described before in the literature [35,39].

The average values obtained by $\mathrm{SPE}_{\mathrm{O}}$ asis HLB technique $\left\{\left(14.0 \mu \mathrm{g} \mathrm{mL}^{-1}\right.\right.$, from $2.4 \mu \mathrm{g} \mathrm{mL}^{-1}$ (RW\#15) to $32.3 \mu \mathrm{g} \mathrm{mL}^{-1}$ (RW\#13)\} are slightly higher than that found with MEPS ${ }_{\mathrm{C} 8}$ technique $\left\{\left(11.4 \mu \mathrm{g} \mathrm{mL}^{-1}\right.\right.$, from $2.9 \mu \mathrm{g} \mathrm{mL}^{-1}$ (RW\#7) to $27.4 \mu \mathrm{g} \mathrm{mL}^{-1}$ (RW\#13)\}.

The highest flavonol content, considering the sum of the target flavonols assayed ( $\sum$ flavonols $/$ MEPSC8 $=27.7 \mu \mathrm{g} \mathrm{mL}^{-1}$ and ( $\sum$ flavonols $/$ SPEOasis HLB $=32.3 \mu \mathrm{g} \mathrm{mL}^{-1}$ ) was determined in red wine \#13, followed by red wines \#20 and \#17, with a flavonol composition around $19.5 \mu \mathrm{g} \mathrm{mL}^{-1}$ and $18.2 \mu \mathrm{g} \mathrm{mL}^{-1}$ obtained by MEPS $\mathrm{C8}$ and $24.8 \mu \mathrm{g} \mathrm{mL}^{-1}$ and $22.6 \mu \mathrm{g} \mathrm{mL}^{-1}$ by $\mathrm{SPE}_{\text {Oasis } \mathrm{HLB}}$, respectively.
Regarding to individual flavonols, myricetin was the most abundant in all investigated wines, followed by quercetin and, in lowest concentration, kaempferol. Myricetin was not found in any of the investigated white wines (\#23-30), however, it was found in all investigated red wines with exception of red wine \#3.

\section{Conclusions}

In conclusion a novel, ultra-fast, sensitive and reproducible MEPS $_{\mathrm{C} 8}$ /UHPLC-PDA-based methodology, was developed, validated and successfully applied to the simultaneous determination of flavonols in wines. As stationary phase a T3 bonding process (HSS T3), which utilizes a trifunctional $C_{18}$ alkyl phases bonded at ligand density that promotes polar compound retention and aqueous mobile phase compatibility, was used. The combination of the shorter running time with a smaller flow rate also reduced drastically the solvent consumption and thus is more environmental friendly. The validated method showed a good performance with regard to selectivity, LODs, LOQs, linearity, extraction yields, 
accuracy and intra/inter-day precisions. The results obtained from the application of the methodology to wine samples suggested that this method can be potentially useful to quantitate each of these compounds and serve as promising alternative to existing methodology for flavonols determination. Moreover, the method can be applied, as an attractive and very promising approach, to the analysis of flavonols in other food matrices, such as vegetables and fruits, due to the possibility of automation, easy to use, fast and low cost analysis, when compared to conventional SPE.

Wine extractions using the MEPS ${ }_{\mathrm{C} 8}$ method provided higher sample throughput, selectivity and sensitivity equal to or slightly greater than the $\mathrm{SPE}_{\mathrm{O} \text { asis } \mathrm{HLB}}$ method.

\section{Acknowledgments}

The authors thank the financial support of FEDER (Transnational Cooperation MAC 2007-2013 Program) through VinSaudeMAC project (MAC/1/M105) and Fundação para a Ciência e Tecnologia through the MS Portuguese Networks (REDE/1508/RNEM/2005) and Pluriannual base funding (QUI-Madeira-674).

\section{References}

[1] H. Halbwirth, I. Puhl, U. Haas, K. Jezik, D. Treutter, K. Stich, J. Agric. Food Chem. 54 (2006) 1479-1485.

[2] R. Lukacin, L. Britsch, Eur. J. Biochem. 249 (1997) 748-757.

[3] R. Lukacin, I. Groning, E. Schiltz, L. Britsch, U. Matern, Arch. Biochem. Biophys. 375 (2000) 364-370.

[4] A. Crozier, J. Burns, A.A. Aziz, A.J. Stewart, H.S. Rabiasz, G.I. Jenkins, C.A. Edwards, M.E. Lean, Biol. Res. 33 (2000) 79-88.

[5] F. de la Pena Moreno, G.P. Blanch, M.L. Ruiz del Castillo, J. Agric. Food Chem. 58 (2010) 11639-11644.

[6] R. Lukacin, F. Wellmann, L. Britsch, S. Martens, U. Matern, Phytochemistry 62 (2003) 287-292.

[7] A. Crozier, I.B. Jaganath, M.N. Clifford, Nat. Prod. Rep. 26 (2009) 1001-1043.

[8] R.B. Rucker, in: C.A. Rice-Evans, L. Packer (Eds.), Flavonoids in Health and Disease, Marcel Dekker, Inc, New York, 2004.

[9] I. Erlund, R. Koli, G. Alfthan, J. Marniemi, P. Puukka, P. Mustonen, P. Mattila, A. Jula, Am. J. Clin. Nutr. 87 (2008) 323-331.

[10] S.N. Nichenametla, T.G. Taruscio, D.L. Barney, J.H. Exon, Crit. Rev. Food Sci. Nutr. 46 (2006) 161-183.

[11] L. Wang, Y.-C. Tu, T.-W. Lian, J.-T. Hung, J.-H. Yen, M.-J. Wu, J. Agric. Food Chem. 54 (2006) 9798-9804.

[12] C. Kandaswami, E. Middleton, Free Radicals in Diagnostic Medicine, Headington Hill Hall, New York, 1994.

[13] M. Exner, M. Hermann, R. Hofbauer, S. Kapiotis, P. Quehenberger, W. Speiser, I. Held, B.M. Gmeiner, Cardiovasc. Res. 50 (2001) 583-588.

[14] N. Yamamoto, J.H. Moon, T. Tsushida, A. Nagao, J. Terao, Arch. Biochem. Biophys. 372 (1999) 347-354.

[15] E.N. Frankel, J. Kanner, J.B. German, E. Parks, J.E. Kinsella, Lancet 341 (1993) 454-457.

[16] E.N. Frankel, A.L. Waterhouse, J.E. Kinsella, Lancet 341 (1993) 1103-1104.

[17] Y. Hanasaki, S. Ogawa, S. Fukui, Free Radic. Biol. Med. 16 (1994) 845-850.

[18] S.V. Nigdikar, N.R. Williams, B.A. Griffin, A.N. Howard, Am.J. Clin. Nutr. 68 (1998) 258-265.

[19] R.L. Walzem, S. Watkins, E.N. Frankel, R.J. Hansen, J.B. German, Proc. Natl. Acad. Sci. U.S.A. 92 (1995) 7460-7464.

[20] M.G. Hertog, E.J. Feskens, P.C. Hollman, M.B. Katan, D. Kromhout, Lancet 342 (1993) 1007-1011.
[21] M.G. Hertog, D. Kromhout, C. Aravanis, H. Blackburn, R. Buzina, F. Fidanza, S. Giampaoli, A. Jansen, A. Menotti, S. Nedeljkovic, et al., Arch. Intern. Med. 155 (1995) 381-386.

[22] M.G. Hertog, E.J. Feskens, D. Kromhout, Lancet 349 (1997) 699.

[23] S.O. Keli, M.G. Hertog, E.J. Feskens, D. Kromhout, Arch. Intern. Med. 156 (1996) 637-642.

[24] P. Knekt, R. Jarvinen, R. Seppanen, M. Hellovaara, L. Teppo, E. Pukkala, A. Aromaa, Am. J. Epidemiol. 146 (1997) 223-230.

[25] M. Furusawa, T. Tanaka, T. Ito, A. Nishikawa, N. Yamazaki, K.-i. Nakaya, N. Matsuura, H. Tsuchiya, M. Nagayama, M. Iinuma, J. Health Sci. 51 (2005) 376-378.

[26] J.P. Hu, M. Calomme, A. Lasure, T. De Bruyne, L. Pieters, A. Vlietinck, D.A. Vanden Berghe, Biol. Trace Elem. Res. 47 (1995) 327-331.

[27] E.E. Deschner, J. Ruperto, G. Wong, H.L. Newmark, Carcinogenesis 12 (1991) 1193-1196.

[28] M. Yoshida, M. Yamamoto, T. Nikaido, Cancer Res. 52 (1992) 6676-6681.

[29] C.D. Stalikas, J. Sep. Sci. 30 (2007) 3268-3295.

[30] A. Sekher Pannala, T.S. Chan, P.J. O'Brien, C.A. Rice-Evans, Biochem. Biophys Res. Commun. 282 (2001) 1161-1168.

[31] W. Bors, C. Michel, Ann N Y Acad Sci. 957 (2002) 57-69.

[32] C. Stalikas, Y. Fiamegos, V. Sakkas, T. Albanis, J. Chromatogr. A 1216 (2009) 175-189.

[33] T. Hyötyläinen, M.-L. Riekkola, Anal. Chim. Acta 614 (2008) 27-37.

[34] P. Alberts, M.A. Stander, A. de Villiers, J. Chromatogr. A 1235 (2012) 92-102.

[35] Z. Spacil, L. Novakova, P. Solich, Talanta 76 (2008) 189-199.

[36] B. Klejdus, J. Vacek, L. Lojkova, L. Benesova, V. Kuban, J. Chromatogr. A 1195 (2008) 52-59.

[37] D. Guillarme, C. Casetta, C. Bicchi, J.L. Veuthey, J. Chromatogr. A 1217 (2010) 6882-6890.

[38] J. Oszmianski, C.Y. Lee, Am. J. Enol. Vitic. 41 (1990) 204-206.

[39] B. Fuhrman, N. Volkova, A. Suraski, M. Aviram, J. Agric. Food Chem. 49 (2001) 3164-3168.

[40] M.P. Saenz-Navajas, V. Ferreira, M. Dizy, P. Fernandez-Zurbano, Anal. Chim. Acta 673 (2010) 151-159.

[41] M.N. Bravo, S. Silva, A.V. Coelho, L.V. Boas, M.R. Bronze, Anal. Chim. Acta 563 (2006) 84-92.

[42] A. Escarpa, M.D. Morales, M.C. González, Anal. Chim. Acta 460 (2002) 61-72.

[43] C.L. Silva, J. Pereira, V.G. Wouter, C. Giró, J.S. Câmara, Talanta 86 (2011) 82-90.

[44] V. Pereira, J.S. Camara, J. Cacho, J.C. Marques, J. Sep. Sci. 33 (2010) 1204-1215.

[45] V. Pereira, M. Pontes, J.S.C. Ã๕mara, J.C. Marques, J. Chromatogr. A 1189 (2008) 435-443.

[46] E. Boselli, M. Minardi, A. Giomo, N.G. Frega, Anal. Chim. Acta 563 (2006)93-100.

[47] I. Novak, P. Janeiro, M. Seruga, A.M. Oliveira-Brett, Anal. Chim. Acta 630 (2008) $107-115$.

[48] I.O. Vvedenskaya, R.T. Rosen, J.E. Guido, D.J. Russell, K.A. Mills, N. Vorsa, J. Agric. Food Chem. 52 (2004) 188-195.

[49] R. Mandrioli, L. Mercolini, D. Lateana, G. Boncompagni, M.A. Raggi, J. Chromatogr. B: Analyt. Technol. Biomed. Life Sci. 879 (2010) 167-173.

[50] D. Guillarme, D.T. Nguyen, S. Rudaz, J.L. Veuthey, J. Chromatogr. A 1149 (2007) 20-29.

[51] M. Abdel-Rehim, J. Chromatogr. A 1217 (2010) 2569-2580.

[52] Z. Altun, M. Abdel-Rehim, Anal. Chim. Acta 630 (2008) 116-123.

[53] L. Novakova, Z. Spacil, M. Seifrtova, L. Opletal, P. Solich, Talanta 80 (2010) 1970-1979.

[54] M.A. Saracino, G. Lazzara, B. Prugnoli, M.A. Raggi, J. Chromatogr. A 1218 (2011) 2153-2159.

[55] J.O. Fernandes, M.A. Ferreira, J. Chromatogr. A 886 (2000) 183-195.

[56] D. Di Majo, L. La Neve, M. La Guardia, A. Casuccio, M. Giammanco, J. Food Compos. Anal. 24 (2011) 265-269.

[57] L.G. Blomberg, Anal. Bioanal. Chem. 393 (2009) 797-807.

[58] J.N. Miller, J.C. Miller, Statistics and Chemometrics for Analytical Chemistry, 4th ed., Prentice Hall Ptr, Essex, UK, 2005.

[59] V.F. Samanidou, M.K. Nika, I.N. Papadoyannis, J. Sep. Sci. 30 (2007) 2391-2400

[60] B. Fuhrman, A. Lavy, M. Aviram, Am. J. Clin. Nutr. 61 (1995) 549-554.

[61] Q. Zhang, G.S. Ma, H. Greenfield, X.Q. Du, K. Zhu, D.R. Fraser, Asia Pac. J. Clin. Nutr. 12 (Suppl.) (2003) S46.

[62] A.A. Bertelli, D.K. Das, J. Cardiovasc. Pharmacol. 54 (2009) 468-476. 